\title{
Emerging potential of cell based therapies for articular cartilage repair and regeneration
}

\begin{abstract}
Osteoarthritis (OA), also known as degenerative arthritis, is a debilitating disease of joints that results in pain, stiffness, reduced movement and eventually requires replacement of the joint. This is the most common form of arthritis especially in elderly population, affecting about 237 million of total population out of which approximately $60 \%$ could result in complete physical disability. Most commonly affected joints are the knee, hip, lower back, ends of hands and fingers. Current available data shows that conventional treatment like exercise, osteotomy, arthroplasty, arthrodesis, and total knee replacement (TKR), only help in relieving pain and do not reverse the cartilage damage or help in cartilage repair or regeneration. Therefore, new advanced treatment modalities are required which can repair the damaged cartilage with healthy chondrocytes and re-establish knee structure and physiology. This review article mainly focuses on different cellular based treatment options like implantation of autologous bone marrow concentrate (BMC), autologous chondrocyte progenitor cells, mesenchymal stem cells (MSCs) and platelet rich plasma (PRP). These cell therapy options may provide long term relief of symptoms and rapid restoration of cartilage function. But it is still under research and not clearly understood whether cell therapy could cure osteoarthritis or simply delay the need for knee replacement.
\end{abstract}

Volume 3 Issue 2 - 2017

\author{
Venkatesh Ponemone, Saniya Gupta, Manish \\ Suthar \\ Fortis Totipotent RX Centre for Cellular Medicine, Fortis \\ Memorial Research Institute, India
}

Correspondence: Venkatesh Ponemone, Executive DirectorClinical Affairs, Totipotent RX Center for Cellular Medicine, Fortis Memorial Research Institute, Sector 44, Gurgaon- I22002, Delhi (NCR), India, Tel +9l-124-496225I,

Email ponemone@gmail.com

Received: June 05, 2017 | Published: November 16, 2017
Abbreviations: ACI, autologous chondrocyte implantation; MSCs, mesenchymal stem cells; PRP, platelet-rich plasma; BMC, autologous bone marrow concentrate; TKR, total knee replacement

\section{Introduction}

Osteoarthritis is a form of arthritis described as a degenerative joint disease that results from the breakdown of articular cartilage and underlying subchondral bone. ${ }^{1,2}$ Cartilage is firm, rubbery, protein substance that serves as a "cushion" between the bones, providing a smooth, gliding surface for joint motion. As the cartilage breaks down, it causes pain, swelling, stiffness and problems moving the joint. ${ }^{3}$ Therefore, Osteoarthritis is a chronic disease and a major cause of disability, characterized by irreversible cartilage degeneration, bony changes of the joints, deterioration of tendons and ligaments, and inflammation of the synoviumas shown in Figure $1 .{ }^{4}$ An initial degeneration, known as the 'pre-OA' state may be reversible spontaneously or through preventive measures, however, if not stopped, the disease progresses to later stages which results in loss of articular cartilage surface integrity, break down of bone and osteophyte formation. ${ }^{3,5}$ OA can affect any joint, but it most often occurs in the knee, hip, lower back and neck, small joints in the finger and base of the big toe (Figure 2) ${ }^{6,7}$

Osteoarthritis of the knee is the most common chronic condition affecting all races, gender and ages, but known to be the most common in elderly and obese people. ${ }^{8,9}$ The knee acts as a conduit for transferring body weight essential for normal human mobility and the menisci is known to maintain the normal function of the knee, distribute load, lubricate the joint and provide joint stability. Injury to the meniscus from ageing cartilage, repetitive activity or trauma results in pain, limits movement and can accelerate the occurrence and development of OA. In general, partial or complete meniscectomy causes OA of the knee. ${ }^{8,10,11}$ While the prevalence of $\mathrm{OA}$ increases with age and causes significant decline in the quality of life of individuals above the age of 65 , there is increasing evidence of $\mathrm{OA}$ in younger population as a result of prior injuries such as anterior cruciate ligament tear or meniscal tears..$^{8,12,13}$

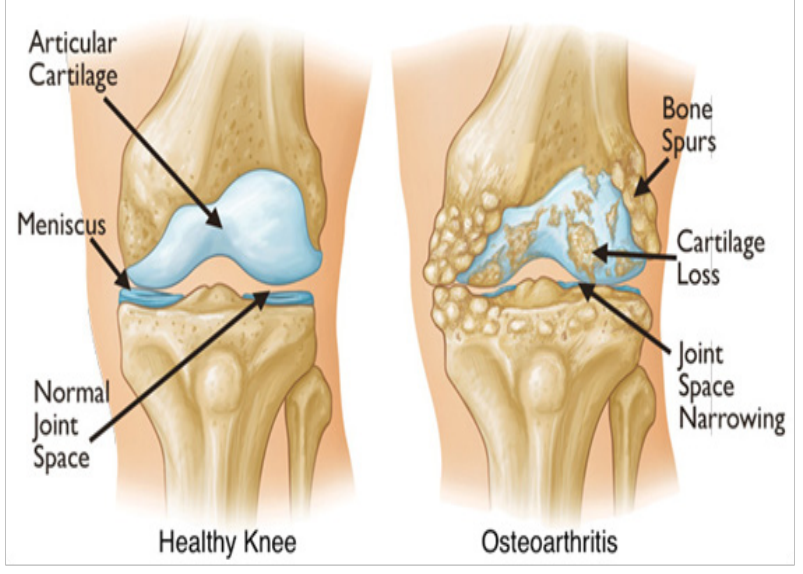

Figure I Comparison schematic between healthy knee and arthritic knee.

Osteoarthritis affects about 237 million of the population, of which an estimated 9 million people alone in United States suffer from symptomatic knee osteoarthritis and it is predicted that an additional 19 million people will be affected by arthritis by $2020 .^{14-17}$ The incidence of chondral defects is frequent with sporting injuries, and in elderly patients specifically $10 \%$ of population over the age of 55 years have troublesome knee pain, and of those, $25 \%$ are severely disabled. ${ }^{18}$ Depending on disease severity, management ranges from conservative treatment to surgical intervention, including total knee replacement. ${ }^{14,19}$ In recent years the number and cost of TKR has increased dramatically between 2001 and 2012 from 305,000 to 610,000 procedures and average cost from $\$ 25,500$ to $\$ 52,000$ (AHRQ report 2014). Further, revision rates of primary TKR are 2.5 
times higher in patients under 65 years of age. It is estimated that the number of total knee revisions will grow by over $600 \%$ by 2030 . $^{7}$

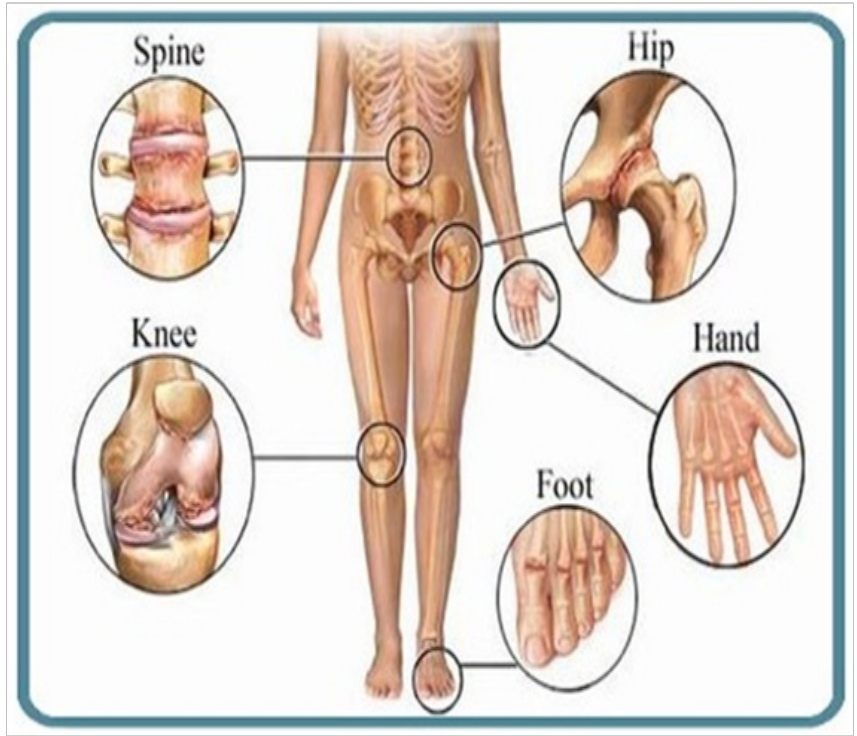

Figure 2 Commonly affected joints by osteoarthritis.

The basic pathophysiological characteristic of knee OA is loss of articular cartilage which is linked to biomechanical and biochemical changes in the cartilage of the knee joint such as, diminished ability to withstand normal mechanical stresses, limited supply of nutrients and oxygen, inadequate synthesis of extracellular matrix components, increased synthesis of tissue-destructive proteinases (matrix metalloproteinases and aggrecanase) and overall apoptosis of chondrocytes. ${ }^{8,9,20,21}$ Although, recently synovial inflammation has been reported as a factor limiting cartilage repair. ${ }^{22}$ Articular cartilage exhibits little or no ability for self-repair, because of the low mitotic ability of chondrocytes, and lack of blood, lymphatic or nerve supply, resulting in progressive tissue loss and dysfunction and presenting as a potential challenge for orthopaedic surgeons. During OA degeneration processes, major modifications of articular cartilage are observed at the tissue, cellular, and molecular levels. ${ }^{23,24}$

Current treatment strategies for OA are focused on pain reduction rather than controlling the disease modification or progression. The management of $\mathrm{OA}$ is broadly divided into non-pharmacological, pharmacological, and surgical treatments. Conventional treatment for $\mathrm{OA}$ includes analgesics, non-steroidal anti-inflammatory drugs (NSAIDS), and opioids for pain reduction, physiotherapy, hyaluronic acid (HA), platelet rich plasma or corticosteroid based intra-articular injections and knee arthroscopic surgery. ${ }^{25,26}$ However, the clinical outcome with these treatments has been modest, mostly requiring $\mathrm{TKR}^{8,27}$ The major limiting factor with prosthetic implants is the lifespan of current implants which remains a concern, especially in young population. TKR is also associated with significant complications that includes deep vein thrombosis and infection, as well as post-surgical joint stiffness and muscle atrophy. ${ }^{28,29}$ The ideal technique for a chondral defect repair should generate a repair tissue with biomechanical properties similar to those of normal hyaline articular cartilage. Abrasion arthroplasty, subchondral bone drilling, and micro-fracture techniques are marrow stimulation techniques that are aimed at perforating subchondral bone to supply blood and Bone Marrow (BM) to the site of lesion. ${ }^{30}$ This results in the recruitment of MSCs, fibrin clot formation, and subsequent fibro cartilage formation. Another approach is the use of autologous or allogenic grafts and mosaicplasty (transplantation of multiple, small, autologous osteochondral grafts), which are limited by marked donorsite morbidity and the availability of such tissue. Moreover, to date, the long-term clinical data did not show any consistent satisfactory results, lacking the applicability to large lesions, doubts remain about the quality and durability of the fibro cartilage that forms after these surgical procedures.

In the last decade, tissue engineering and regenerative medicine techniques have improved the use of autologous cellular therapy that has capacity to proliferate and differentiate without an immunological reaction, disease transmission, or donor-site morbidity. There are three main types of cells used in clinical trial for knee OA including Mesenchymal Stem Cells, articular chondrocytes and bone marrow cell concentrate. Among the various cell therapies, MSCs have shown promising results for the treatment of OA. However, there are several limitations with the use of MSCs and researchers are focusing on the beneficial effects of BMC for the treatment of knee OA. The mechanism of action of bone marrow derived cell therapy in tissue regeneration are related to the secretion of a number of cytokines, chemokines, and growth factors (GFs), which can improve angiogenesis, suppress inflammation, inhibit apoptosis, and stimulate endogenous repair. Cell based therapies have a huge potential to contribute to novel therapeutic strategies for the repair of chondral or osteochondral defects. In the last few years, cell-based therapies have been shown to reverse the symptoms and pathophysiology of OA. ${ }^{31}$ With recent development in the field of regenerative medicine, there are many clinical studies that are underway to explore the capacity of stem cells to regenerate articular cartilage thus suggesting a potential to be translated from bench to bedside. This review article aims at assessing the most promising cell based treatment modalities for Osteoarthritis of knee that augment cartilage repair and regeneration. We also talk about the cartilage repair mechanism using various cell sources and treatment strategies.

\section{Autologous chondrocyte implantation (ACI)}

The most widely used surgical approach for treating large, fullthickness chondral lesions is the autologous chondrocyte implantation (ACI) technique, which is considered as the first application of a cell engineering strategy in orthopaedic surgery. ACI relies on repopulating the native damaged cartilage with mature cultured autologous chondrocytes and has successfully been used for cartilage repair and regeneration. ${ }^{32,33}$ For ACI, a small biopsy of articular cartilage is taken and cultured to extract chondrocytes for treatment. However, this procedure is invasive and has certain limitations that is de-differentiation of the chondrocytes during the culture expansion with concomitant down-regulation of cartilage-specific markers and limited life span following transplantation. ${ }^{34}$ ACI is a twostep procedure, one where autologous chondrocytes are harvested from cartilage, isolated, and cultured, and in second procedure the cultured cells are implanted into the defect. This procedure has been modified and tissue-engineered membranes are used as scaffolds for growing and expanding the chondrocytes, known as matrix guided autologous chondrocyte implantation (MACI). This has enhanced the applicability of the ACI technique, thus permitting a completely arthroscopic procedure in the knee and ankle. ${ }^{35}$ MACI implantation allows for delivery of the implant via mini-arthrotomy or in some cases via arthroscopy. However, the outcome of these surgical treatment strategies is still controversial. Nevertheless, ACI and 
MACI have major limitations that are difficult to overcome: the need for 2 surgical procedures, the limited chondrogenesis of expanded chondrocytes, and their unsuitability to articular cartilage defects as a result of poor biological properties of chondrocytes from patients. ${ }^{36-39}$ Further the difficulties involved in obtaining a sufficient number of chondrocytes for auto-transplantation and the donor site morbidity are major issues, and also histological analysis reveals the repaired tissue to be insufficient. 32,40

\section{Mesenchymal stem cells (MSCs)}

MSCs are easy to harvest and isolate with minimal donor site morbidity, having the ability to expand into chondrocytes. Therefore, treatment with MSC have been actively explored in the field of tissue engineering and cartilage repair. ${ }^{7}$ Regardless of the MSC origin, they have the capacity to differentiate into many cell types depending on the environment, stimuli and culture conditions used, including cells of connective tissue lineages such as bone, fat, cartilage and muscle. ${ }^{41,42}$ Also, MSCs are promising cell sources for tissue engineering and cellbased therapeutics because of their self-renewal and differentiation ability and are of major interest for researchers in the treatment of arthritis, in particular knee OA. The goal of stem cells is to support the process of cartilage repair and regeneration of the knee joint. ${ }^{43}$ Even synovial fluid inside the joints contain mesenchymal stem cells (MSCs) which can differentiate into chondrocytes. However, there is limited quantity of MSCs available in the joint and the process of differentiation is slow and sluggish. ${ }^{44,45}$ Therefore external administration of MSCs may help to improve the cartilage repair and regeneration. The bone marrow derived stromal cells have shown promising results for repairing the damaged cartilage tissue.

Intra-articular injections of MSCs in preclinical studies have shown a significant improvement in the function, however the results have been inconsistent on cartilage regeneration and restoration. Some studies have not shown any significant improvement in pain and function with disease progression, while some researchers have successfully shown disease modulation. ${ }^{7}$ In a monoiodoacetate induced rat model of $\mathrm{OA}$, treatment with intra-articular injections of bone marrow derived MSCs resulted in the animals being able to distribute significantly greater weight through the affected limb. However, in contrast to this functional improvement, no statistically significant difference was observed between the treatment and control groups with respect to cartilage and subchondral bone pathology and synovial inflammation. ${ }^{46}$ The use of MSC based therapy in conjunction with micro-fracture technique was observed in a surgically induced chondral lesion goat model. This combination therapy resulted in improved integration of tissue and super quality tissue repair with formation of collagen type II. ${ }^{47}$

Similar to pre-clinical results, clinical studies utilizing intraarticular injections of MSCs have shown reproducible results in terms of pain reduction and functional improvement, however the disease modification has been inconsistent. Centeno et al. ${ }^{48,49}$ reported significant improvement in both chondral and meniscus volume in case studies when treated with a combination of bone marrow derived MSCs, platelet lysate and Bone marrow concentrate. Centeno et al. ${ }^{50}$ later published a case series of 339 patients, where in sixty percent $(60 \%)$ of patients reported $>50 \%$ pain relief and forty percent $(40 \%)$ reported $>75 \%$ pain relief at 11 months following administration of MSCs in patients requiring total knee replacement. The pain and functional improvement observed with MSC therapy in osteoarthritis patients is attributed due to its biological mechanism of action that is strong anti-inflammatory effect. Further, the observed disease modification in studies that use combination therapy suggests that the efficacy of MSC therapies may be influenced by additional agents including concentrated platelets and hyaluronic acid.

Karudo et al. ${ }^{51}$ and colleagues successfully treated a femoral condyle cartilage defect with autologous Bone Marrow MSCs and their results showed cartilage repair with Hyaline type tissue formation. Another study by Emadedin et al. ${ }^{52}$ used single intraarticular injection of autologous culture expanded bone marrow MSCs which resulted in pain and functional improvement with increased cartilage thickness. However, they observed an increase in pain after 6 months, suggesting that a repeat injection might be beneficial. Investigators in a cohort study did not find any significant difference in the clinical outcomes between bone marrow derived MSCs versus autologous chondrocyte implantation that are being transplanted in the area of chondral defects. ${ }^{53}$ These results indicate that transplanted MSCs might result in hypertrophic chondrocyte differentiation and expression of collagen type $\mathrm{X}$ which is associated with endochondral ossification. $^{54,55}$

For cartilage regeneration, the MSC harvesting procedure is considered less invasive procedure than that of chondrocytes, even if, in the standard procedure, 2 surgical steps are still required because of the need for cell harvesting and expansion before the final implantation of cells into the lesion site. Moreover, MSCs can be harvested without impairing normal articular cartilage, thus preventing donor-site morbidity. However, the major limitation of MSCs is that it requires technique that needs cell selection and expansion in the laboratory, and, consequently, the transplant can be performed in two operative procedures with the need for a Good Manufacturing Practice (GMP) facility. Major pitfalls associated with MSC application for articular cartilage regeneration is the expression of cartilage hypertrophy markers such as collagen type X, matrix metalloproteinase-13, alkaline phosphatase, parathyroid hormonerelated protein receptor and vascular endothelial growth factor when MSCs are induced to undergo chondrogenesis and this hypertrophy results in ossification of cartilage tissue, which is a major concern of MSCs for regenerating articular cartilage defects. ${ }^{56-59}$ Some repair chondrocytes may undergo hypertrophic differentiation, followed by matrix calcification, vascular invasion, and endochondral ossification leading to new bone formation in an articular cartilage defect site. It has been well reported that bone marrow derived MSCs have an intrinsic differentiation program reminiscent of endochondral bone formation. ${ }^{60}$ Pre-differentiation of MSCs will be essential in clinical applications in order to ensure appropriate lineage commitment and to avoid undesired heterotopic tissue formation.

\section{Platelet-rich plasma (PRP)}

PRP is an autologous blood product witha high concentration of platelets in a small volume of plasma. Platelets contain significant amounts of cytokines and growth factors that are capable of stimulating cell growth, proliferation, vascularization, tissue regeneration, and collagen synthesis. Delivery of high concentration of cytokines and growth factors to damaged tissues by PRP is considered to have a beneficial effect on tendon and cartilage tissue repair and regeneration. ${ }^{61}$ In some in vitro and in vivo studies, antiinflammatory and reparative effects of PRP on cartilage, tendon, and ligament recovery have been shown. ${ }^{62-64}$ The rationale for the use of 
PRP is to stimulate the natural healing cascade and tissue regeneration by release of platelet-derived factors directly at the site of treatment. ${ }^{65}$

Several studies have reported PRP to be clinically safe and effective in reducing pain following intra-articular injection of PRP up to 12 months following treatment. ${ }^{66-69}$ Positive outcomes are mostly found more commonly in younger patients with Milles severe knee OA. In this subgroup of the population PRP does show clear benefit over hyaluronic acid in pain reduction and clinical function scores. However, middle-aged patients with moderate to severe OA demonstrated no significant benefit with PRP over HA. ${ }^{45,70}$

Knop et al. ${ }^{71}$ conducted a comprehensive and systematic search of the literature on the use of PRP in the treatment of OA of the knee. A total of 23 studies were selected with nine being controlled trials and of these seven randomized, which included total of 725 patients. The group receiving PRP showed improvement in pain and joint function when compared to placebo and HA for up to two year follow-up.

Sánchez et al.$^{68}$ compared PRP and HA in 176 patients with knee OA in a double-blinded, randomized control trial. Treatment with PRP reduced the WOMAC index by $50 \%$ (primary outcome) and showed a trend of improvement in secondary outcomes with no statistical significance. Say et al. ${ }^{72}$ published a study where they compared a single PRP injection with three HA injections in individuals with knee OA. The study showed clinical improvement with both treatments after three and six months of the procedure, however there was a better response in patients treated with PRP.

Kon et al..$^{45}$ treated three groups of 50 patients with knee OA who received PRP, high and low molecular weight HA respectively and the clinical responses measured by IKDC and EQ-VAS scores were higher in patients that received PRP injections compared to HA. The low molecular weight HA performed better than the high molecular weight; however, still lower than the response obtained by PRP. In addition to clinical response, Sampson et al. performed ultrasound to measure the articular cartilage thickness one year after PRP injection in 14 patients studied where it showed no benefit in terms of increase in the thickness of the articular cartilage. ${ }^{73}$ This could be attributed to low sensitivity of the ultrasound imaging method to detect those changes.

In the year 2011, Dhollander et al. ${ }^{74}$ treated five patients with PRP with chondral lesions of the patella with cartilage debridement The patients were evaluated by magnetic resonance imaging (MRI) before the procedure and after 12 and 24 months. The clinical benefits were observed in clinical scores (VAS, KOOS subscale), except for the Tegner score. However, there was no difference in MOCART score (Magnetic Resonance Observation of Cartilage Tissue Repair), and only stability of the lesions took place. Similarly Hart et al. ${ }^{75}$ evaluated PRP response in 50 patients with knee OA using MRI assessment before and one year after PRP injection. The degree of cartilage damage was measured by modified Outer bridge Grading Scale. There was no change in the cartilage thickness in $94 \%$ of cases and a slight increase (less than $1 \mathrm{~mm}$ ) was recorded in three cases $(6 \%)$ at the end of 1 year follow-up.

Although, literature suggests a favorable use of PRP for the treatment of $\mathrm{OA}$, but analysis of the available evidence suggested uncertain results due to lack of standardization of outcome measures and therefore, well designed clinical trials are needed to establish the proof of concept. ${ }^{76}$

\section{Autologous bone marrow concentrate (BMC)}

Numerous autologous biologic agents are available worldwide, and autologous bone marrow concentrate represents the next generation ortho-biologic agent for cartilage defects. BMC has emerged as an important biological tool for the orthopedic surgeons because it is one of the few forms of delivering stem cells and growth factors which is currently approved by the United States Food and Drug Administration (FDA). Although minimally manipulated bone marrow aspirate and Platelet Rich Plasma (PRP) have not been regulated as HCT/Ps to date, the FDA has regulated these technologies with rules on point of care application and minimal manipulation.

$\mathrm{BMC}$ is obtained using density-gradient centrifugation of bone marrow aspirate (BMA) which is easily harvested from various anatomical locations, typically from the posterior superior iliac crest. The composition of these nucleated cells is diverse that includes MSCs, Hematopoietic Stem Cells (HSCs), Monocyte Precursor cells, Macrophages, T cells, B cells, Dendritic Antigen Presenting Cells, Natural Killer Cells and Neutrophils. ${ }^{77-79}$ Nevertheless, BMC serves as a source of growth factors, including platelet-derived growth factor (PDGF), transforming growth factor-beta (TGF- $\beta$ ), and bone morphogenetic protein (BMP)-2 and BMP-7, which are assigned to have anabolic and anti-inflammatory effects that facilitate regeneration of tissue ${ }^{80-82}$ The resultant BMC after centrifugation has been shown to provide elevated levels of HSCs, MSCs, platelets, chemokines and cytokines that are injected intra-articularly for treating cartilage defects. BMC thus possess anti-inflammatory, angiogenic and immunomodulatory properties that can potentially enhance cartilage repair. $^{83}$

Basic science and animal model studies have reported promising results for using BMC in treating cartilage pathology. ${ }^{84,85}$ These preclinical trials have led to a few small clinical studies. A 2012 review by Filardo et al. ${ }^{70}$ found 2 pre-clinical papers and 5 clinical trials focusing on the use of BMC in cartilage regeneration. Although these studies have small numbers, they offer a good start at unraveling the clinical potential of BMC.

In clinical studies, BMC has been used to treat cartilage pathology, including both OA and focal chondral defects. ${ }^{86-88}$ Several studies have reported BMC to be effective in treatment of early knee OA and moderate focal chondral defects..$^{82,89-91}$ Centeno et al. ${ }^{89}$ compared the treatment of osteoarthritis with injections of BMC combined with PRP and platelet lysate, with and without adipose tissue. The data indicates that there is no significant difference between the 2 groups. $\mathrm{BMC}$ injections for knee OA showed encouraging outcomes with a relative low rate of Adverse Events (AEs). Addition of an adipose graft to BMC did not provide a detectible benefit over BMC alone treated group. Similarly, Kim et al. reported Bone Marrow Aspirate Concentrate (BMAC) injection significantly improved both knee pain and functions in the patients with degenerative arthritis of knee. Also, the injection would be more effective in early to moderate phases. ${ }^{91}$

In the comparative study conducted by Kyrch et al. ${ }^{92}$ the early MRI appearance between cartilage defects treated with a scaffold versus a scaffold with PRP or BMAC were compared. Results showed that the patients treated with scaffold implantation augmented with BMAC had improved cartilage maturation with greater fill closer to that of superficial native hyaline cartilage at 12 months suggesting superior role of BMC over PRP. 
The safety of BMC treatment for knee OA is far greater than total knee arthroplasty. A 2014 study reveals that more than 15,000 arthroplasty patients prospectively reported a Serious Adverse Event (SAE) rate of $5.6 \%$ with a $0.2 \%$ mortality rate. Although relatively low for such an invasive procedure, this rate of SAEs does lend for the study of less invasive alternatives to total knee arthroplasty. BMC treatment appears to be a safe and feasible treatment procedure for cartilage repair, and there are readily available point of care systems in the market that allow cells to be processed at the patient's bed side and delivered in the same sitting, eliminating the need for a 2 sitting procedure unlike autologous chondrocyte or MSC implantation in patients. The idea of transplanting the BM concentrate to the lesion site, permits the cells to be processed directly in the operating room, without the need for a laboratory phase, thus allowing the transplantation to be performed in 'one step', therefore reducing the costs, risks and eliminating the need for requiring a GMP facility. Most of the studies are in a pilot phase or early clinical studies which concludes safety and a preliminary efficacy. However, there is a need for well conducted randomized controlled trials to establish the efficacy of BMC in treating cartilage defects. Table 1 summarizes the clinical studies conducted using the various cell sources mentioned above, that is, ACI, MSCs, PRP or BMC and their corresponding results.

Table I Recent clinical trials involving stem cells in cartilage regeneration

\begin{tabular}{|c|c|c|c|c|c|c|}
\hline $\begin{array}{l}\text { S. } \\
\text { No. }\end{array}$ & $\begin{array}{l}\text { Author and } \\
\text { year }\end{array}$ & Cell type & No. of patients & Follow-up & Description & Results \\
\hline I & Jiang $Y$ et al. ${ }^{93}$ & $\begin{array}{l}\text { Chondrocyte } \\
\text { Derived } \\
\text { Progenitor Cells }\end{array}$ & 15 & 12 months & $\begin{array}{l}\text { Compared with } \\
\text { bone mesenchymal } \\
\text { stem cells (BMSCs), } \\
\text { chondrogenic } \\
\text { potential was better }\end{array}$ & $\begin{array}{l}\text { Clinical scores of all patients showed } \\
\text { improvement; function improved and } \\
\text { pain was relieved. Ectopic calcification } \\
\text { and vascularization was observed in } 4 \\
\text { patients }\end{array}$ \\
\hline 2 & $\begin{array}{l}\text { Davatchi } \mathrm{F} \text { et } \\
\text { al. }^{94}\end{array}$ & f(BMSCs) & 3 & 5 years & $\begin{array}{l}\text { Intra-articular } \\
\text { injection of cultured } \\
\text { cells }\end{array}$ & $\begin{array}{l}\text { Long-term follow-up of stem cell } \\
\text { injection showed good prognosis in } \\
\text { early-stage OA }\end{array}$ \\
\hline 3 & $\begin{array}{l}\text { Sampson A et } \\
\text { al. }{ }^{95}\end{array}$ & $\begin{array}{l}\text { BMC followed } \\
\text { by PRP }\end{array}$ & 125 & I48 Days & $\begin{array}{l}\text { Retrospective cases: } \\
\text { Intra-articular } \\
\text { injection of BMC } \\
\text { followed by PRP } \\
\text { injection at } 8 \text { weeks }\end{array}$ & $\begin{array}{l}\text { No adverse effects were reported in all } \\
\text { the patients with short term benefits } \\
\text { with respect to reduction in pain in } \\
\text { patients with moderate-to-severe OA. }\end{array}$ \\
\hline 4 & Shapiro S et al. ${ }^{96}$ & $\mathrm{BMC}$ & 25 & 6 months & $\begin{array}{l}\text { Treatment group: } \\
\text { IA injection of BMC } \\
\text { Control Group: IA } \\
\text { injection of saline }\end{array}$ & $\begin{array}{l}\text { Early results show no significant } \\
\text { difference between the two groups. Pain } \\
\text { reduced significantly in all the patients } \\
\text { and no adverse effects were reported. }\end{array}$ \\
\hline 5 & Vega A et al. ${ }^{97}$ & BMSCs & BMSCs:I5 HA:I5 & 12 months & $\begin{array}{l}\text { RCT using } \\
\text { allogenic BMSCs } \\
\text { and compared to } \\
\text { hyaluronic acid }\end{array}$ & $\begin{array}{l}\text { Compared to the HA group, functional } \\
\text { improvement and quality of regenerated } \\
\text { cartilage are enhanced in BMSC group. }\end{array}$ \\
\hline 6 & Sekiya I et al. ${ }^{98}$ & $\begin{array}{l}\text { Synovial } \\
\text { Mesenchymal } \\
\text { Stem Cells } \\
\text { (SMSCs) }\end{array}$ & 10 & $37-80$ months & $\begin{array}{l}\text { Culture expanded } \\
\text { synovial } \\
\text { mesenchymal stem } \\
\text { cells using human } \\
\text { serum }\end{array}$ & $\begin{array}{l}\text { MRI scores, Lysholm scores and } \\
\text { quantitative histology show meaningful } \\
\text { improvement following SMSC } \\
\text { transplantation. }\end{array}$ \\
\hline 7 & Koh YG et al. ${ }^{99}$ & $\begin{array}{l}\text { Adipose-derived } \\
\text { Mesenchymal } \\
\text { Stem cells } \\
\text { (ADSCs) }\end{array}$ & $\begin{array}{l}\text { ADSC: } 40 \\
\text { Microfracture: } 40\end{array}$ & 2 years & $\begin{array}{l}\text { RCT comparing } \\
\text { ADSC + micro- } \\
\text { fracture with micro- } \\
\text { fracture alone }\end{array}$ & $\begin{array}{l}\text { Treatment group showed better } \\
\text { improvement in pain and radiological } \\
\text { symptoms as compared to control group. }\end{array}$ \\
\hline 8 & Kim YS et al. ${ }^{100}$ & ADSCs & 20 & 2 years & $\begin{array}{l}\text { IA injections of } \\
\text { cultured MSCs with } \\
\text { fibrin glue }\end{array}$ & $\begin{array}{l}\text { Clinical and MRI scores show a } \\
\text { significant improvement }\end{array}$ \\
\hline 9 & Orozco L et al. ${ }^{101}$ & BMSCs & 12 & 2 years & $\begin{array}{l}\text { IA injection of } \\
\text { cultured bone MSCs }\end{array}$ & $\begin{array}{l}\text { Pain was relieved after I year of } \\
\text { treatment which continued through year } \\
\text { 2. MRI showed better quality of cartilage } \\
\text { in year } 2 \text { as compared to year I. }\end{array}$ \\
\hline 10 & Wong KL et al. ${ }^{102}$ & BMSCs & $\begin{array}{l}\text { BMSC+HA: } 28 \\
\text { HA: } 28\end{array}$ & 2 years & $\begin{array}{l}\text { RCT high tibial } \\
\text { osteotomy+ micro- } \\
\text { fracture }\end{array}$ & $\begin{array}{l}\text { Treatment group showed effective } \\
\text { improvement in clinical and cartilage } \\
\text { repair tissue scores as compared to } \\
\text { control group. }\end{array}$ \\
\hline
\end{tabular}


Table Continued...

\begin{tabular}{|c|c|c|c|c|c|c|}
\hline $\begin{array}{l}\text { S. } \\
\text { No. }\end{array}$ & $\begin{array}{l}\text { Author and } \\
\text { year }\end{array}$ & Cell type & No. of patients & Follow-up & Description & Results \\
\hline II & Centeno et al. ${ }^{89}$ & $\mathrm{BMC}+\mathrm{PRP}$ & 681 (840 knees) & 10 months & $\begin{array}{l}\text { Retrospective study } \\
\text { comparing BMC } \\
\text { injection with or } \\
\text { without adipose graft }\end{array}$ & $\begin{array}{l}\text { Improvement in lower extremity } \\
\text { functional score with significant } \\
\text { reduction in pain following BMC+PRP } \\
\text { injection. Adipose graft did not provide } \\
\text { significant benefit over BMC alone. }\end{array}$ \\
\hline 13 & Lee KBL et al. ${ }^{104}$ & BMSCs & $\begin{array}{l}\text { BMSC+HA+Micro- } \\
\text { fracture:35 BMSC+ } \\
\text { Patch: } 35\end{array}$ & 2 years & $\begin{array}{l}\text { Prospective } \\
\text { comparative study } \\
\text { on safety and short- } \\
\text { term efficacy }\end{array}$ & $\begin{array}{l}\text { Micro-fracture with BMSC and } \\
\text { Hyaluronic acid injection showed } \\
\text { comparable results to BMSC with } \\
\text { patch, however, it is a minimally invasive } \\
\text { procedure making it superior. }\end{array}$ \\
\hline 14 & Gobbi et al. ${ }^{87}$ & BMC & 15 & 24 months & $\begin{array}{l}\text { BMC+collagen } \\
\text { matrix in grade } \\
\text { IV full thickness } \\
\text { cartilage lesions }\end{array}$ & $\begin{array}{l}\text { Histology and MRI findings showed } \\
\text { lesion coverage with hyaline like cartilage } \\
\text { in all patients. }\end{array}$ \\
\hline 15 & Buda et al. ${ }^{105}$ & $\begin{array}{l}\text { BMC + platelet } \\
\text { gel }\end{array}$ & 20 & 24 months & $\begin{array}{l}\text { Arthroscopic } \\
\text { procedure with } \\
\text { implantation of BMC } \\
\text { with platelet gel }\end{array}$ & $\begin{array}{l}\text { Significant clinical improvement in Koos } \\
\text { score which increased over time. Also, } \\
\text { regeneration of subchondral bone and } \\
\text { cartilage tissue was observed. }\end{array}$ \\
\hline
\end{tabular}

\section{Mechanism of action towards the repair of cartilage defects}

The mechanism of cartilage repair and regeneration is not clearly understood till date. Medical expertise and scientists have used a number of methodologies to determine the exact mechanism behind cartilage regeneration process.

In autologous cultured chondrocyte implantation, the transplanted chondrocyte progenitor cells may exhibit their activity by two ways; either through direct cartilage regeneration or through paracrine effect in which transplanted cells induce other cells to differentiate into cartilage cells by releasing chemokines and growth factors. However, it is difficult to prove the extent of cell retention and survival post transplantation. Studies have shown that absence of implanted autologous chondrocytes in the rabbit model leads to complete failure of the ACI procedure. ${ }^{106}$ Using a goat model, a recent study by Dell'Accio et al. ${ }^{107}$ assessed the structural contribution made by fluorescently labelled chondrocytes implanted into fullthickness cartilage defects in lateral femoral condyles. They reported that implanted cells are capable of participating in the formation of repair tissue denoted by collagen type II expression in the regions populated with the fluorescently tagged implanted chondrocytes and, furthermore, can persist in the defects for as long as 14 weeks postsurgery. The exact function of this collagen remains obscure, but it is suggested that it may exert other influences on the extracellular matrix such as altering the accumulation of proteoglycans, ${ }^{108}$ thereby modifying the diffusion properties of the matrix. In addition, it has the potential of being more susceptible to digestion by collagenase enzymes, making it a candidate for relatively easy turnover. ${ }^{109}$ It could indicate an active process of endochondral ossification leading to integration of the newly-formed articular cartilage with the subchondral bone.

The extracellular matrix of articular cartilage is the primary target of osteoarthritic cartilage degradation. However, cartilage cells have a pivotal role during osteoarthritis, as they are mainly responsible for the anabolic-catabolic balance required for matrix maintenance and tissue function. In addition to the severe changes in the extracellular matrix, the cells also display abnormalities during osteoarthritic cartilage degeneration, such as alterations in cell number through processes like proliferation and (apoptotic) cell death.

Medicos have been using Platelet Rich Plasma (PRP) for establishment of healthier cartilage. Intra-articular injections of PRP are given to the patients, these platelets are activated by endogenous thrombin and/or intra-articular collagen. ${ }^{110}$ Once activated, there is secretion of growth factors by degranulation of the alpha granules. ${ }^{111}$ Platelet-derived growth factor (PDGF), interleukin-1 receptor antagonist (IL-1RA), soluble receptor of tumor necrosis factor $\alpha$ (TNF$\mathrm{RI})$, transforming growth factor $\beta$ (TGF- $\beta$ ), platelet factor 4 (PF4), vascular endothelial growth factor (VEGF), epidermal growth factor (EGF), insulin-like growth factor (IGF), osteocalcin (Oc), osteonectin (On), fibrinogen, vitronectin, fibronectin and thrombospondin-1 (TSP-1)are among the secreted substances. ${ }^{12}$ Many of these factors act as anti-catabolic and anti-inflammatory agents. The antagonist of IL-1 receptor inhibits activation of NFkB gene which regulates the cytokine involved in apoptosis and inflammation process. ${ }^{110,113}$ Moreover, the soluble receptors of the tumor necrosis factor bind to TNF- $\alpha$, preventing its interaction with cellular receptors and its pro-inflammatory signaling. TGF- $\beta_{1}$ also acts as a factor inhibiting cartilage degradation, regulating and enhancing gene expression of tissue inhibitors of metalloproteinases (TIMP-1). ${ }^{114}$ Other factors such as IGF-1, PDGF and TGF- $\beta_{1}$ favor the stabilization of cartilage by controlling the metabolic functions of chondrocytes and subchondral bone, maintaining the homeostasis between the synthesis and degradation of proteoglycans, and stimulating the proliferation of chondrocytes. ${ }^{115,116}$ It was also found that platelet growth factors stimulate synovial fibroblasts to synthesize hyaluronic acid. ${ }^{115}$

The use of BMC has also been successful in few cases of OA of knee. $\mathrm{BMC}$ is an autologous bone marrow-derived product containing 
a heterogeneous mixture of cells including, but not limited to, MSCs, HSCs and platelets, as well as bioactive molecules such as cytokines. HSCs present in the BMC exhibit support to the vasculature system by differentiating into blood cells; HSCs have also been shown to provide cell-to-cell contact with MSCs, stimulating osteogenesis. Additionally, the platelet component of BMC releases growth factors to initiate stem cell migration to the injury site and provides adhesion sites for the migrating stem cells. ${ }^{62}$

In addition to having multi-lineage differentiation capacity, multipotent stromal cells obtained from bone marrow and other tissues possess several properties that are unique to these cells in order to bring about tissue regeneration. In particular, BMSCs are known to preferentially home and accumulate to the site of injury and inflammation. The SDF1/CXCR4 pathway is a key regulator for BMSC migration, and, in the absence of SDF1 signal, migration of these cells to the bone tissue has been found to be impaired. ${ }^{117,118}$ These cells are also known to secrete a large number of growth factors, cytokines, and chemokines that carry out different functions. This paracrine activity of MSCs is thought to be one of the major means by which these cells mediate anti-inflammatory, anti-apoptotic, antifibrotic, angiogenic, mitogenic, and wound-healing properties that have proliferative effects on cells. ${ }^{42,44,62,83}$

The study by Cassano et al. ${ }^{119}$ reviewed the growth factor and cytokine levels between PRP and BMC. They found that BMC had $172.5 \mathrm{x}$ the concentration of vascular endothelial growth factor (VEGF), 78x the concentration of interleukin-8 (IL-8), 4.6x the concentration of interleukin-1beta (IL- $\beta), 3.4 x$ the concentration of transforming growth factor- $\beta_{2}$ (TGF- $\beta_{2}$ ) and $1.3 \mathrm{x}$ the concentration of platelet derived growth factor (PDGF). A possible explanation for the increased concentration of growth factors and cytokines in the $\mathrm{BMC}$ samples relates to the concentration of platelets it contains. The alpha granules of platelets contain TGF- $\beta$, PDGF, VEGF along with fibroblast growth factor (FGF), BMP, and insulin-like growth factor (IGF). ${ }^{120,121}$

MSCs are promising cell source for regeneration of focal cartilage lesions, as they can be differentiated into chondrocytes when subjected to suitable cocktail of differentiation media. ${ }^{122}$ It has been shown that TGF- $\beta$ is a critical molecule essential for MSC chondrogenic differentiation. ${ }^{54}$ Minute levels of active TGF- $\beta$ is sufficient to stimulate proteoglycan and type II collagen synthesis ${ }^{123}$ and also increase the number of chondrocytes formed. ${ }^{124}$ TGF- $\beta$ signaling has been shown to stimulate early transcription factor Sox-9 which resulted in elevated expression of collagen type II and aggrecan significantly. ${ }^{125}$ MSCs have also been shown to elicit differentiation of resident and non-resident cells to functional tissue, catalyzing restoration of degenerative tissue. ${ }^{126,127}$

The principal determinant factor behind effective chondrogenicity is the vehicle which delivers the MSCs for regeneration. Moshaverinia et al. ${ }^{128}$ developed a novel co-delivery system based on TGF- $\beta_{1}$ loaded RGD-coupled alginate microspores encapsulating MSCs and investigated MSC chondrogenic differentiation in the alginate microspheres. The results revealed sustained delivery of TGF- $\beta_{1}$ from the alginate microspheres and positive chondrogenic differentiation. Furthermore, Extracellular matrix (ECM) provides a niche for cell migration, differentiation and attachment. They are comprised of various physiomechanical and chemical cues which guide the stem cell lineage. Subbiah and colleagues described the use of a cellderived ECM platform in which the crosslinking density is tunable and evaluated the effect on human MSC (hMSC) differentiation. The study demonstrated that tunable cross-linked cell-derived ECM provides a physiological platform, guides cell differentiation and leads to rapid generation and attachment of progenitor cells leading to healing. ${ }^{129}$

Alternate strategies for fabricating advanced tissue engineered cartilage constructs are of increasing importance because of the ongoing demand. Tissue engineering techniques mimic the native extracellular matrix for tissue regeneration by employing a synergy of cells, growth factors and scaffolds. ${ }^{130,131}$ Three dimensional (3D) bio-printing method for developing new organ for transplantation, prosthetics and in regenerative medicine has emerged as a breakthrough over the last few years. This is a powerful technology that can provide patients with severe disease condition with personalized treatments. This novel technology designs and fabricates 3D scaffolds that closely resemble native tissue. Major bio-printing methods include microextrusion, inkjet bioprinting, laser assisted bioprinting, integrated tissue organ printer (ITOP) and robotic bioprinting of organs. Researchers are working on developing vasculature in $3 \mathrm{D}$ bioprinting transplant for nutrient delivery and oxygen supply which can be a strong therapeutic approach for problems like osteoarthritis. ${ }^{132}$ Technologies like biofabrication and 3D bioprinting allow the specific placement of cells and tissues. When modular assemblies (micro tissue units, cellular building blocks or spheroids) are combined with structural scaffold components and automated biofabrication technology, they create a functional cartilage and offer potential approach in recovering damaged articular cartilage. ${ }^{133}$

Mature articular cartilage is an avascular structure, which receives its nutrition via diffusion from the synovial fluid. Its unique structure and function is attributable to the dense packing of collagen fibers and mature chondrocytes and lack of blood vessels. Mature articular cartilage contains inhibitors to angiogenesis including Troponin I and Chondromodulin-1 in the avascular layers of the cartilage but are absent in the supporting subchondral bone and spongiosa allowing VEGF to promote a vascular supply. ${ }^{134-136}$ Therefore, this is clearly important in full thickness chondral defects where the subchondral bone can release growth factors and cytokines to support cartilage repair. Maes et al. ${ }^{135}$ have clearly shown the importance of VEGF for epiphyseal blood supply and cartilage development using mice as an animal model. VEGF deficient mice showed altered growth plates, ossification centers and joint dysplasia. Oxygen tension is a key factor that is triggering VEGF production via the stimulation of hypoxia inducible factor-1 (HIF-1). Lund-Olesen ${ }^{136}$ has shown that after a traumatic effusion there is a reduction in the oxygen tension leading to HIF-1 and VEGF production. Clearly this situation would match a chondral injury pattern with an associated effusion or hemarthrosis and therefore increased VEGF production. Alongside oxygen tension other factors have been shown to stimulate VEGF production including IL-1 via the Mitogen Activated Protein Kinase signaling pathway as demonstrated by Murata and colleagues. ${ }^{134}$ Thus, highlighting the complex interplay between the cytokine cascades.

IL- 8 is a powerful cytokine for neutrophil chemotaxis and activation as part of the inflammatory response. Chauffer et al. ${ }^{137}$ have shown that mechanical stress can also increase IL-8 from chondrocytes. Thus damaged cartilage, which is under increased mechanical stress, would release more IL-8 attracting neutrophils to the affected area. IL-8 has also reported to promote homing of bone marrow derived cells to the site of injury, including MSCs. Hou et al. ${ }^{138}$ has shown that IL-8 enhances the angiogenic potential of mesenchymal cells via increasing VEGF production. This would appear a clear benefit in promoting angiogenesis and tissue healing especially in full thickness chondral defects. 
Interleukin-1 (IL-1) is subdivided into IL- 1 and IL- $1-\beta .{ }^{139}$ The IL-1 has more of an intracellular effect whereas it is IL-1- $\beta$ that modulates the immune response and downstream effects via stimulation of matrix metalloproteinases.IL-1- $\beta$ is produced by local monocytes and macrophages involved in the inflammatory response and is known to contribute to inflammation in human joints and can degrade cartilage via its metalloproteinase action. ${ }^{140}$ The effect of this is blocked by the interleukin antagonist IL-1 receptor antagonist (IL-1RA). ${ }^{140}$ It has been reported that there is a relative imbalance of the IL-1- $\beta$ : IL1 RA ratio with a deficiency of IL-1RA in osteoarthritis allowing IL$1-\beta$ leading to cartilage degradation. ${ }^{141}$ Cassano and colleagues has demonstrated an increase in the IL-1- $\beta$ but also IL-1RA in BMAC, therefore neutralizing the effect of the raised IL-1- $\beta .{ }^{119}$

PDGF has an established role in wound healing but also functions to promote collagen synthesis and contributes angiogenesis in subchondral injuries. ${ }^{142}$ Although PDGF has a minor role in cartilage repair it does have a synergistic action with suppression of IL-1- $\beta$ cartilage degradation.

IGF-1 is an essential mediator of cartilage homeostasis by achieving the balanced chondrocytes proliferation ${ }^{143}$ and IGF has been shown to enhance MSC chondrogenesis by a mechanism similar to that of TGF- $\beta .{ }^{144}$ IGF-1 can repair cartilage defects more efficiently with collagen type II filled matrix. ${ }^{116}$

These studies clearly demonstrate the importance of thoroughly characterizing specific molecules and growth factors present in the microenvironment/ bone marrow concentrate for chondrogenic differentiation potential. Thus, a new concept in stem cell therapy sees BMC as a therapeutic means to positively influence the microenvironment of the stem cells already present in the diseased tissue and to direct those cells for regeneration activities instead of expecting the transplanted cells to contribute directly to de novo tissue production. ${ }^{145-149}$

\section{Future perspectives}

In the near future, cell-based therapy could be widely used for the treatment of OA as it potentially offers substantial benefits for knee OA patients and may reduce the cost of therapy. However, there are still some unanswered questions regarding the best cell source, treatment mechanism, methodology for transplanting cells, effective cell dose, combinational therapy or single cell source and efficacy that need to be resolved before their widespread use. Therefore, well designed RCTs are urgently required to evaluate the clinical benefits of each cellular based treatment modality that is, ACI, MSCs, BMC and PRP in cartilage repair.

\section{Acknowledgements}

None.

\section{Conflict of interest}

The author declares no conflict of interest.

\section{References}

1. Poulet B, Staines KA. New developments in osteoarthritis and cartilage biology. Curr Opin Pharmacol. 2016;28:8-13.

2. Arden N, Bianco F, Cooper C, et al. Atlas of osteoarthritis. USA: Springer healthcare communications; $2015.21 \mathrm{p}$.
3. Brittberg M, Gomoll AH, Canseco JA, et al. Cartilage repair in the degenerative ageing knee: A narrative review and analysis. Acta Orthop. 2016;87(Suppl 363):26-38.

4. Alshami AM. Knee osteoarthritis related pain: a narrative review of diagnosis and treatment. Int J Health Sci (Qassim). 2014;8(1):85-104.

5. Buckwalter JA, Mankin HJ. Articular cartilage: tissue design and chondrocyte-matrix interactions. Instr Course Lect. 1998;47:477-486.

6. Healthwise Staff. Joints often affected by Osteoarthritis. WebMD; 2015.

7. Freitag J, Bates D, Boyd R, et al. Mesenchymal stem cell therapy in the treatment of osteoarthritis: reparative pathways, safety and efficacy - a review. BMC Musculoskelet Disord. 2016;17:230.

8. Yubo M, Yanyan L, Li L, et al. Clinical efficacy and safety of mesenchymal stem cell transplantation for osteoarthritis treatment: A meta-analysis. PLOS ONE. 2017;12(4):e0175449.

9. Uth K, Trifonov D. Stem cell application for osteoarthritis in the knee joint: A mini review. World J Stem Cells. 2014;6(5):629-636.

10. Wang M, Yuan Z, Ma N, et al. Advances and prospects in stem cells for cartilage regeneration. Stem Cells Int. 2017;2017:4130607.

11. Korpershoek JV, de Windt TS, Hagmeijer MH, et al. Cell-based meniscus repair and regeneration: at the brink of clinical translation? a systematic review of preclinical studies. Orthop J Sports Med. 2017;5(2):2325967117690131.

12. Hafez AR, Alenazi AM, Kachanathu SJ, et al. Knee osteoarthritis: a review of literature. Phys Med Rehabil Int. 2014;1(5):8.

13. Ajuied A, Wong F, Smith C, et al. Anterior cruciate ligament injury and radiologic progression of knee osteoarthritis: a systematic review and meta-analysis. Am J Sports Med. 2014;42(9):2242-2252.

14. Wood AM, Brock TM, Heil K, et al. A review on the management of hip and knee osteoarthritis. Int J Chronic Dis. 2013;2013:845015.

15. Zhang Y, Jordan JM. Epidemiology of osteoarthritis. Clin Geriatr Med. 2010;26(3):355-369.

16. Sacks JJ, Luo YH, Helmick CG. Prevalence of specific types of arthritis and other rheumatic conditions in the ambulatory health care system in the United States, 2001-2005. Arthritis Care Res (Hoboken). 2010;62(4):460-464

17. WHO priority medicines for europe and the world update. BP6 12 Osteoarthritis; 2013.

18. Nuki G. Osteoarthritis. In: Luqmani R, et al. editor. Textbook of orthopaedics. Mosby, Chicago, USA: trauma and rheumatology; 2008. 193 p.

19. Lawrence RC, Felson DT, Helmick CG, et al. Estimates of the prevalence of arthritis and other rheumatic conditions in the United States. Part II. Arthritis Rheum. 2008;58(1):26-35.

20. Buja LM, Krüger GRF. Netter's Illustrated Human Pathology. 2nd ed. Suite, Elsevier Inc, USA: Springer; 2014. 390 p.

21. Michael JW, Schlüter Brust KU, Eysel P. The epidemiology, etiology, diagnosis, and treatment of osteoarthritis of the knee. Dtsch Arztebl Int. 2010;107(9):152-162

22. Fibel KH, Hillstrom HJ, Halpern BC. State-of-the-Art management of knee osteoarthritis. World J Clin Cases. 2015;3(2):89-101.

23. Berenbaum F. Osteoarthritis as an inflammatory disease (osteoarthritis is not osteoarthrosis!). Osteoarthritis Cartilage. 2013;21(1):16-21.

24. Sokolove J, Lepus CM. Role of inflammation in the pathogenesis of osteoarthritis: latest findings and interpretations. Ther Adv Musculoskelet Dis. 2013;5(2):77-94. 
25. Murrell WD, Anz AW, Badsha H, et al. Regenerative treatments to enhance orthopaedic surgical outcome. PMR. 2015;7(4 Suppl):S41-52.

26. Hogan MV, Walker GN, Cui LR, et al. The role of stem cells and tissue engineering in orthopaedic sports medicine: current evidence and future directions. Arthroscopy. 2015;31(5):1017-1021.

27. Zhang W, Ouyang H, Dass CR, et al. Current research on pharmacologic and regenerative therapies for osteoarthritis. Bone Res. 2016;4:15040.

28. Schairer WW, Zhang AL, Feeley BT. Hospital readmissions after primary shoulder arthroplasty. J Shoulder Elbow Surg. 2014;23(9):1349-1355.

29. Urquhart DM, Hanna FS, Brennan SL, et al. Incidence and risk factors for deep surgical site infection after primary total hip arthroplasty: a systematic review. J Arthroplasty. 2010;25(8):1216-1222.

30. Richter W. Mesenchymal stem cells and cartilage in situ regeneration. $J$ Intern Med. 2009;266(4):390-405.

31. Koelling S, Miosge N. Stem cell therapy for cartilage regeneration in osteoarthritis. Expert Opin Biol Ther. 2009;9(11):1399-1405.

32. Brittberg M, Lindahl A, Nilsson A, et al. Treatment of deep cartilage defects in the knee with autologous chondrocyte transplantation. $N$ Engl J Med. 1994;331(14):889-895.

33. Peterson L, Minas T, Brittberg M, et al. Two- to 9-year outcome after autologous chondrocyte transplantation of the knee. Clin Orthop Relat Res. 2000;(374):212-234.

34. Brittberg M, Peterson L, Sjögren Jansson E, et al. Articular cartilage engineering with autologous chondrocyte transplantation. A review of recent developments. J Bone Joint Surg Am. 2003;85(Suppl 3):109-115.

35. Jakob RP. AMIC technique for cartilage repair, a single-step surgical intervention as compared to other methods. Eur Cell Mater. 2006;12(Suppl 1):26.

36. Peterson L, Vasiliadis HS, Brittberg M, et al. Autologous chondrocyte implantation: a long-term follow-up. Am J Sports Med. 2010;38(6):11171124 .

37. Henderson IJ, Tuy B, Connell D, et al. Prospective clinical study of autologous chondrocyte implantation and correlation with MRI at three and 12 months. J Bone Joint Surg Br. 2003;85(7):1060-1066.

38. Henderson I, Francisco R, Oakes B, et al. Autologous chondrocyte implantation for treatment of focal chondral defects of the knee: a clinical, arthroscopic, MRI and histologic evaluation at 2 years. Knee. 2003;12(3):209-216.

39. Minas T, Peterson L. Advanced techniques in autologous chondrocyte transplantation. Clin Sports Med. 1999;18(1):13-44.

40. Horas U, Pelinkovic D, Herr G, et al. Autologous chondrocyte implantation and osteochondral cylinder transplantation in cartilage repair of the knee joint. A prospective, comparative trial. J Bone Joint Surg Am. 2003;85A:185-192.

41. Baghaban Eslaminejad M, Malakooty Poor E. Mesenchymal stem cells as a potent cell source for articular cartilage regeneration. World J Stem Cells. 2014;6(3):344-354.

42. Caplan AI. Adult mesenchymal stem cells for tissue engineering versus regenerative medicine. J Cell Physiol. 2007;213(2):341-347.

43. Davatchi F, Abdollahi BS, Mohyeddin M, et al. Mesenchymal stem cell therapy for knee osteoarthritis. Preliminary report of four patients. Int $J$ Rheum Dis. 2001;14(2):211-215.

44. Gupta PK, Das AK, Chullikana A, et al. Mesenchymal stem cells for cartilage repair in osteoarthritis. Stem Cell Res Ther. 2012;3(4):25.
45. Kon E, Mandelbaum B, Buda R, et al. Platelet-rich plasma intra-articular injection versus hyaluronic acid visco-supplementation as treatments for cartilage pathology: from early degeneration to osteoarthritis. Arthroscopy. 2011;27(11):1490-1501.

46. Van Buul GM, Siebelt M, Leijs MJ, et al. Mesenchymal stem cells reduce pain but no degenerative changes in a mono-iodoacetate rat model of osteoarthritis. J Orthop Res. 2014;32(9):1167-1174.

47. Singh JA, Kundukulam J, Riddle DL, et al. Early postoperative mortality following joint arthroplasty: a systematic review. J Rheumatol. 2011;38(7):1507-1513.

48. Centeno C, Kisiday J, Freeman M, et al. Partial regeneration of the human hip via autologous bone marrow nucleated cell transfer: a case study. Pain Physician. 2006;9(3):253-256.

49. Centeno C, Busse D, Kisiday J, et al. Regeneration of meniscus cartilage in a knee treated with percutaneously implanted autologous mesenchymal stem cells. Med Hypotheses. 2008;71(6):900-908.

50. Centeno C, Schultz J, Cheever M, et al. Safety and complications reporting on the re-implantation of culture-expanded mesenchymal stem cells using autologous platelet lysate technique. Curr Stem Cell Res Ther. 2011;5(1):81-93.

51. Karudo R, Ishida K, Matsumoto T, et al. Treatment of a full-thickness articular cartilage defect in the femoral condyle of an athlete with autologous bone-marrow stromal cells. Osteoarthritis Cartilage. 2007; 15(2):226-231.

52. Emadedin M, Aghdami N, Taghiyar L, et al. Intra-articular injection of autologous mesenchymal stem cells in six patients with knee osteoarthritis. Arch Iran Med. 2012;15(7):422-428.

53. Nejadnik H, Hui JH, Feng Choong EP, et al. Autologous bone marrow-derived mesenchymal stem cells versus autologous chondrocyte implantation: an observational cohort study. Am J Sports Med. 2010;38(6):1110-1116.

54. Johnstone B, Hering TM, Caplan AI, et al. In vitro chondrogenesis of bone marrow-derived mesenchymal progenitor cells. Exp Cell Res. 1998;238(1):265-272.

55. Shen $G$. The role of type $X$ collagen in facilitating and regulating endochondral ossification of articular cartilage. Orthod Craniofac Res. 2005;8(1):11-17.

56. Sekiya I, Vuoristo JT, Larson BL, et al. In vitro cartilage formation by human adult stem cells from bone marrow stroma defines the sequence of cellular and molecular events during chondrogenesis. Proc Natl Acad Sci USA. 2012;99(7):4397-4402.

57. Mwale F, Girard Lauriault PL, Wang HT, et al. Suppression of genes related to hypertrophy and osteogenesis in committed human mesenchymal stem cells cultured on novel nitrogen-rich plasma polymer coatings. Tissue Eng. 2006;12(9):2639-2647.

58. Mwale F, Stachura D, Roughley P, et al. Limitations of using aggrecan and type $\mathrm{X}$ collagen as markers of chondrogenesis in mesenchymal stem cell differentiation. J Orthop Res. 2006;24(8):1791-1798.

59. Pelttari K, Winter A, Steck E, et al. Premature induction of hypertrophy during in vitro chondrogenesis of human mesenchymal stem cells correlates with calcification and vascular invasion after ectopic transplantation in SCID mice. Arthritis Rheum. 2006;54(10):3254-3266.

60. Somoza RA, Welter JF, Correa D, et al. Chondrogenic differentiation of mesenchymal stem cells: challenges and unfulfilled expectations. Tissue Eng Part B Rev. 2014;20(6):596-608.

61. Dragoo JL, Wasterlain AS, Braun HJ, et al. Platelet-rich plasma as a treatment for patellar tendinopathy: a double-blind, randomized controlled trial. Am J Sports Med. 2014;42(3):610-618. 
62. Steinert AF, Middleton KK, Araujo PH, et al. Platelet-rich plasma in orthopedic surgery and sports medicine: pearls, pitfalls and new trends in research. Oper Tech Orthop. 2012;22(2):91-103.

63. Rayegani SM, Raeissadat SA, Taheri MS, et al. Does intra articular platelet rich plasma injection improve function, pain and quality of life in patients with osteoarthritis of the knee? A randomized clinical trial. Orthop Rev Pavia. 2014;6(3):5405.

64. Jayabalan P, Hagerty S, Cortazzo MH. The use of platelet-rich plasma for the treatment of osteoarthritis. Phys Sports med. 2014;42(3):53-62.

65. McArthur BA, Dy CJ, Fabricant PD, et al. Long term safety, efficacy, and patient acceptability of hyaluronic acid injection in patients with painful osteoarthritis of the knee. Patient Prefer Adherence. 2012;6:905-910.

66. Spakova T, Rosocha J, Lacko M, et al. Treatment of knee joint osteoarthritis with autologous platelet rich plasma in comparison with hyaluronic acid. Am J Phys Med Rehabil. 2012;91(5):411-417.

67. Cerza F, Carnì S, Carcangiu A, et al. Comparison between hyaluronic acid and platelet-rich plasma, intra-articular infiltration in the treatment of gonarthrosis. Am J Sports Med. 2012;40(12):2822-2827.

68. Sanchez M, Fiz N, Azofra J, et al. A randomized clinical trial evaluating plasma rich in growth factors (PRGF-endoret) versus hyaluronic acid in theshort-term treatment of symptomatic knee osteoarthritis. Arthroscopy. 2012;28(8):1070-1078.

69. Patel S, Dhillon S, Aggarwal S, et al. Treatment with platelet-rich plasma is more effective than placebo for knee osteoarthritis: a prospective, double-blind, randomized trial. Am J Sports Med. 2013;41(2):356-364.

70. Filardo G, Kon E, Di Martino A, et al. Platelet-rich plasma vs hyaluronic acid to treat knee degenerative pathology: study design and preliminary results of a randomized controlled trial. BMC Musculoskelet Disord. 2012;13:229.

71. Knop E, Paula LE, Fuller R. Platelet-rich plasma for osteoarthritis treatment. Rev Bras Reumatol Engl Ed. 2016;56(2):152-164.

72. Say F, Gurler D, Yener K, Bülbül M, et al. Platelet-rich plasma injection is more effective than hyaluronic acid in the treatment of knee osteoarthritis. Acta Chir Orthop Traumatol Cech. 2013;80(4):278-283.

73. Sampson S, Reed M, Silvers H, et al. Injection of platelet-rich plasma in patients with primary and secondary knee osteoarthritis: a pilot study. Am J Phys Med Rehabil. 2010;89(12):961-969.

74. Dhollander AAM, De Neve F, Almqvist KF, et al. Autologous matrix-induced chondrogenesis combined with platelet-rich plasma gel: technical description and a five pilot patients report. Knee Surg Sports Traumatol Arthrosc. 2011;19(4):536-542.

75. Hart R, Safi A, Komzak M, Jajtner P, et al. Platelet-rich plasma in patients with tibiofemoral cartilage degeneration. Arch Orthop Trauma Surg. 2013;133(9):1295-1301.

76. Sheth U, Simunovic N, Klein G, et al. Efficacy of autologous platelet-rich plasma use for orthopaedic indications: A meta-analysis. J Bone Joint Surg Am. 2012;94(4):298-307.

77. Sesia SB, Duhr R, Medeiros da Cunha C, et al. Anti-inflammatory/tissue repair macrophages enhance the cartilage-forming capacity of human bone marrow-derived mesenchymal stromal cells. J Cell Physiol. 2015;230(6):1258-1269.

78. Ikehara A, Maeda H, Kimura T, et al. Bone marrow-derived macrophages are associated with androgen modulated prostate regeneration. Prostate. 2012;72(1):1-11.

79. Zhang Y, Wang F, Chen J, et al. Bone marrow-derived mesenchymal stem cells versus bone marrow nucleated cells in the treatment of chondral defects. Int Orthop. 2012;36(5):1079-1086.
80. Indrawattana $\mathrm{N}$, Chen $\mathrm{G}$, Tadokoro $\mathrm{M}$, et al. Growth factor combination for chondrogenic induction from human mesenchymal stem cell. Biochem Biophys Res Commun. 2004;320(3):914-919.

81. Schnabel LV, Mohammed HO, Miller BJ, et al. Platelet rich plasma (PRP) enhances anabolic gene expression patterns in flexor digitorum superficialis tendons. J Orthop Res. 2007;25(2):230-240.

82. Chahla J, Cinque ME, Shon JM, et al. Bone marrow aspirate concentrate for the treatment of osteochondral lesions of the talus: a systematic review of outcomes. J Exp Orthop. 2016;3(1):33.

83. Sampson S, Botto van Bemden A, Aufiero D. Autologous bone marrow concentrate: review and application of a novel intra-articular orthobiologic for cartilage disease. Phys SportsMed. 2013;41(3):7-18.

84. Fortier LA, Potter HG, Rickey EJ, et al. Concentrated bone marrow aspirate improves full-thickness cartilage repair compared with microfracture in the equine model. J Bone Joint Surg Am. 2010;92(10):1927-1937.

85. Saw KY, Hussin P, Loke SC, et al. Articular cartilage regeneration with autologous marrow aspirate and hyaluronic acid: an experimental study in a goat model. Arthroscopy. 2009;25(12):1391-1400.

86. Gigante A, Cecconi S, Calcagno S, et al. Arthroscopic knee cartilage repair with covered microfracture and bone marrow concentrate. Arthrosc Tech. 2012;1:e175-180.

87. Gobbi A, Karnatzikos G, Scotti C, et al. One-step cartilage repair with bone marrow aspirate concentrated cells and collagen matrix in full-thickness knee cartilage lesions: results at 2-year follow-up. Cartilage. 2011;2(3):286-299.

88. Gobbi A, Chaurasia S, Karnatzikos G, et al. Matrix-induced autologous chondrocyte implantation versus multipotent stem cells for the treatment of large patellofemoral chondral lesions: a nonrandomized prospective trial. Cartilage. 2015;6(2):82-97.

89. Centeno C, Pitts J, Al Sayegh H, et al. Efficacy of autologous bone marrow concentrate for knee osteoarthritis with and without adipose graft. Biomed Res Int. 2014;2014:370621.

90. Hauser RA, Orlofsky A. Regenerative injection therapy with whole bone marrow aspirate for degenerative joint disease: a case series. Clin Med Insights Arthritis Musculoskelet Disord. 2013;6:65-72.

91. Kim JD, Lee GW, Jung GH, et al. Clinical outcome of autologous bone marrow aspirates concentrate (BMAC) injection in degenerative arthritis of the knee. Eur J Orthop Surg Traumatol. 2014;24(8):1505-1511.

92. Krych AJ, Sousa PL, King AH, et al. The effect of cartilage injury after arthroscopic stabilization for shoulder instability. Orthopedics. 2015;38(11):e965-969.

93. Jiang Y, Cai Y, Zhang W, et al. Human cartilage-derived progenitor cells from committed chondrocytes for efficient cartilage repair and regeneration. Stem Cells Transl Med. 2016;5(6):733-744.

94. Davatchi F, Sadeghi Abdollahi B, Mohyeddin M, et al. Mesenchymal stem cell therapy for knee osteoarthritis: 5 years follow-up of three patients. Int J Rheum Dis. 2016;19(3):219-225.

95. Sampson S, Smith J, Vincent H, et al. Intra-articular bone marrow concentrate injection protocol: short-term efficacy in osteoarthritis. Regen Med. 2016;11(6):511-520.

96. Shapiro SA, Kazmerchak SE, Heckman MG, et al. A prospective, single-blind, placebo-controlled trial of bone marrow aspirate concentrate for knee osteoarthritis. Am J Sports Med. 2016;45(1):82-90.

97. Vega A, Martin Ferrero MA, Canto FD, et al. Treatment of knee osteoarthritis with allogeneic bone marrow mesenchymal stem cells: a randomized controlled trial. Transplantation. 2015;99(8):1681-1690. 
98. Sekiya I, Muneta T, Horie M, et al. Arthroscopic transplantation of synovial stem cells improves clinical outcomesin knees with cartilage defects. Clin Orthop Relat Res. 2015;473(7):2316-2326.

99. Koh YG, Kwon OR, Kim YS, Adipose-derived mesenchymal stem ce1ls with microfracture versus microfracture alone: 2-year follow-up of a prospective randomized trial. Arthroscopy. 2016;32(1):97-109.

100. Kim YS, Choi YJ, Lee SW, et al. Assessment of clinical and MRI outcomes after mesenchymal stem cell implantationin patients with knee osteoarthritis: a prospective study. Osteoarthritis Cartilage. 2016;24(2):237-245.

101. Orozco L, Munar A, Soler R, et al. Treatment of knee osteoarthritis with autologous mesenchymal stem cells: two year follow-up results. Transplantation. 2014;97(11):e66-68.

102. Wong KL, Lee KBL, Tai BC, et al. Injectable cultured bone marrow-derived mesenchymal stem cells in varus knees with cartilage defects undergoing high tibial osteotomy: a prospective, randomized controlled clinical trial with 2 years' follow-up. Arthroscopy. 2013;29(12):2020-2028.

103. Saw KY, Anz A, Siew Yoke Jee C, et al. Articular cartilage regeneration with autologous peripheral blood stem cells versus hyaluronic acid: a randomized controlled trial. Arthroscopy. 2013;29(4):684-694.

104. Lee KBL, Wang VTZ, Chan YH, et al. A novel, minimally-invasive technique of cartilage repair in the human knee using arthroscopic microfracture and injections of mesenchymal stem cells and hyaluronic acid-a prospective comparative study on safety and short-term efficacy. Ann Acad Med Singapore. 2012;41(11):511-517.

105. Buda R, Vannini F, Cavallo M, et al. Osteochondral lesions of the knee: a new one-step repair technique with bone-marrow-derived cells. J Bone Joint Surg Am. 2010;92(2):2-11.

106. Brittberg M, Nilsson A, Lindahl A, et al. Rabbit articular cartilage defects treated with autologous cultured chondrocytes. Clin Orthop Relat Res. 1996;(326):270-283

107. Dell' Accio F, De Bari C, Luyten FP. Microenvironment and phenotypic stability specify tissue formation by human articular cartilage-derived cells in vivo. Exp Cell Res. 2003;287(1):16-27.

108. Chen Q, Linsenmayer C, Gu H, et al. Domains of type X collagen: alteration of cartilage matrix by fibril association and proteoglycan accumulation. J Cell Biol. 1992;117(3):687-694.

109. Schmid TM, Popp RG, Linsenmayer TF. Hypertrophic cartilage matrix: type $\mathrm{X}$ collagen, supramolecular assembly and calcification. Ann NY Acad Sci. 1990;580:64-73.

110. Harrison S, Vavken P, Kevy S, et al. Platelet activation by collagen provides sustained release of anabolic cytokines. Am J Sports Med. 2011;39(4):729-734.

111. Ahmad Z, Howard D, Brooks RA, et al. The role of platelet-rich plasma in musculoskeletal science. JRSM Short Rep. 2012;3(6):40.

112. Lacci KM, Dardik A. Platelet-rich plasma: support for its use in wound healing. Yale J Biol Med. 2010;83(1):1-9.

113. Van Buul GM, Koevoet WLM, Kops N, et al. Platelet-rich plasma releasateinhibitsinflammatory processes in osteoarthritic chondrocytes. Am J Sports Med. 2011;39:2362-2370.

114. Mix KS, Sporn MB, Brinckerhoff CE, et al. Novel inhibitors of matrix metalloproteinase gene expression as potential therapies for arthritis. Clin Orthop Relat Res. 2004;427:129-137.

115. Anitua E, Sánchez M, Nurden AT, et al. Platelet-released growth factors enhance the secretion of hyaluronic acid and induce hepatocyte growth factor production by synovial fibroblasts from arthritic patients. Rheumatology. 2007;46(12):1769-1772.
116. Schmidt MB, Chen EH, Lynch SE. A review of the effects of insulin-like growth factor and platelet-derived growth factoron in vivo cartilage healing and repair. Osteoarthritis Cartilage. 2005;14(5):403-412.

117. Wynn RF, Hart CA, Corradi Perini C, et al. A small proportion of mesenchymal stem cells strongly expresses functionally active CXCR4 receptor capable of promoting migration to bone marrow. Blood. 2004;104(9):2643-2645.

118. Dar A, Goichberg P, Shinder V, et al. Chemokine receptor CXCR4-dependent internalization and resecretion of functional chemokine SDF-1 by bone marrow endothelial and stromal cells. Nat Immunol. 2005;6(10):1038-1046.

119. Cassano JM, Kennedy JG, Ross KA, et al. Bone marrow concentrate and platelet-rich plasma differ in cell distribution and interleukin 1 receptor antagonist protein concentration. Knee Surg Sports Traumatol Arthrosc. 2016;26(1):333-342.

120. Oh JH, Kim W, Park KU, et al. Comparison of the cellular composition and cytokine-release kinetics of various platelet-rich plasma preparations. Am J Sports Med. 2015;43(12):3062-3070.

121. Holton J, Imam M, Ward J, et al. The basic science of bone marrow aspirate concentrate in chondral injuries. Orthop Rev (Pavia). 2016;8(3):6659.

122. Pittenger MF, Mackay AM, Beck SC, et al. Multilineage potential of adult human mesenchymal stem cells. Science. 1999;284(5411):143-147.

123. Vinatier C, Bouffi $\mathrm{C}$, Merceron $\mathrm{C}$, et al. Cartilage tissue engineering: towards a biomaterial-assisted mesenchymal stem cell therapy. Curr Stem Cell Res Ther. 2009;4(4):318-329.

124. Bian L, Zhai DY, Tous E, et al. Enhanced MSC chondrogenesis following delivery of TGF- $\beta 3$ from alginate microspheres within hyaluronic acid hydrogels in vitro and in vivo. Biomaterials. 2011;32(27):6425-6434.

125. Kawakami Y, Rodriguez León J, Izpisúa Belmonte JC. The role of TGF betas and Sox9 during limb chondrogenesis. Curr Opin Cell Biol. 2006;18(6):723-729.

126. Chamberlain G, Fox J, Ashton B, et al. Concise review: mesenchymal stem cells: their phenotype, differentiation capacity, immunological features, and potential for homing. Stem Cells. 2007;25(11):2739-2749.

127. Liechty KW, MacKenzie TC, Shaaban AF, et al. Human mesenchymal stem cells engraft and demonstrate site-specific differentiation after in utero transplantation in sheep. Nat Med. 2000;6(11):1282-1286.

128. Moshaverinia A, Xu X, Chen $\mathrm{C}$, et al. Dental mesenchymal stem cells encapsulated in an alginate hydrogel co-delivery microencapsulation system for cartilage regeneration. Acta Biomaterialia. 2013;9(12):93439350 .

129. Subbiah R, Hwang MP, Du P, et al. Tunable cross-linked cell-derived extracellular matrix guides cell fate. Macromol Biosci. 2016;16(11):17231734.

130. Sundaramurthi D, Rauf S, Hauser CAE. 3D bioprinting technology for regenerative medicine applications. International Journal of Bioprinting. 2016;2(2):9-26.

131. Schons BS, Hooper GJ, Woodfield TBF. Modular tissue assembly strategies for biofabrication of engineered cartilage. Ann Biomed Eng. 2017;45(1):100-114.

132. Shukunami C, Oshima Y, Hiraki Y. Chondromodulin-I and tenomodulin: a new class of tissue-specific angiogenesis inhibitors found in hypovascular connective tissues. Biochem Biophys Res Commun. 2005;333(2):299-307.

133. Moses MA, Wiederschain $\mathrm{D}, \mathrm{Wu} \mathrm{I}$, et al. Troponin $\mathrm{I}$ is present in human cartilage and inhibits angiogenesis. Proc Natl Acad Sci USA. 1999;96(6):2645-2650 
134. Murata M, Yudoh K, Nakamura H, et al. Distinct signaling pathways are involved in hypoxia- and IL-1-induced VEGF expression in human articular chondrocytes. J Orthop Res. 2006;24(7):1544-1554.

135. Maes C, Stockmans I, Moermans K, et al. Soluble VEGF isoforms are essential for establishing epiphyseal vascularization and regulating chondrocyte development and survival. J Clin Invest. 2004;113(2):188-199.

136. Lund Olesen K. Oxygen tension in synovial fluids. Arthritis Rheum. 1970;13(6):769-776.

137. Chauffier K, Laiguillon MC, Bougault C, et al. Induction of the chemokine IL-8/Kc by the articular cartilage: possible influence on osteoarthritis. Joint Bone Spine. 2012;79(6):604-609.

138. Hou Y, Ryu CH, Jun JA, et al. IL-8 enhances the angiogenic potential of human bone marrow mesenchymal stem cells by increasing vascular endothelial growth factor. Cell Biol Int. 2014;38(9):1050-1059.

139. Barakat AF, Elson CJ, Westacott CI. Susceptibility to physiological concentrations of IL-1beta varies in cartilage at different anatomical locations on human osteoarthritic knee joints. Osteoarthritis Cartilage. 2002;10(4):264-269.

140. Jacques C, Gosset M, Berenbaum F, et al. The role of IL-1 and IL-1Ra in joint inflammation and cartilage degradation. Vitam Horm. 2006;74:371403.

141. Fernandes JC, Martel Pelletier J, Pelletier JP. The role of cytokines in osteoarthritis pathophysiology. Biorheology. 2002;39(1-2):237-246.
142. Civinini R, Nistri L, Martini C, et al. Growth factors in the treatment of early osteoarthritis. Clin Cases Miner Bone Metab. 2013;10(1):26-29.

143. Yoon DM, Fisher JP. Effects of exogenous IGF-1 delivery on the early expression of IGF-1 signaling molecules by alginate embedded chondrocytes. Tissue Eng Part A. 2008;14(7):1263-1273.

144. Fukumoto T, Sperling JW, Sanyal A, et al. Combined effects of insulin-like growth factor-1 and transforming growth factor-beta1 on periostea mesenchymal cells during chondrogenesis in vitro. Osteoarthritis Cartilage. 2013;11(1):55-64.

145. Agency for Healthcare Research and Quality. Nationwide Inpatient Sample (NIS), Healthcare Cost and Utilization Project (HCUP), USA: Sptinger; 2014.

146. Dhillon MS, Behera P, Patel S, et al. Orthobiologics and platelet rich plasma. Indian J Orthop. 2014;48(1):1-9.

147. Grigolo B, Lisignoli G, Desando G, et al. Osteoarthritis treated with mesenchymal stem cells on hyaluronan-based scaffold in rabbit. Tissue Eng Part C Methods. 2009;15(4):647-658.

148. Wakitani S, Goto T, Pineda SJ, et al. Mesenchymal cell-based repair of large, full-thickness defects of articular cartilage. J Bone Joint Surg Am. 1994;76(4):579-592.

149. Zhang W, Moskowitz RW, Nuki G, et al. OARSI recommendations for the management of hip and knee osteoarthritis, Part II: OARSI evidence-based, expert consensus guidelines. Osteoarthritis Cartilage. 2008;16(2):137-162. 